\title{
What do You Know About Audit Quality in Malaysian Small and Medium Audit Firms?
}

\author{
Nur Amira Rodzi and Aida Hazlin Ismail* \\ Faculty of Accountancy, \\ Universiti Teknologi MARA, Malaysia
}

\begin{abstract}
Audit quality has been addressed and is being discussed globally, throughout the years. The Enron Corporation and WorldCom cases have affected the reputation of the audit profession. The credibility of auditors also has become more questionable as the auditors' function in identifying mistakes and fraud is being debated by the public. However, the issue of audit quality has only focused on big firms only. There is shortage of studies that focussed on audit quality in small and medium audit firms. In line with this issue, this study aimed to investigate the relationship between top management support, auditor's experience and auditor's accountability on audit quality amongst small-medium audit firms in Malaysia. By employing the Attribution Theory, the study utilised purposive sampling. The data used in this study was primary data obtained through questionnaires from external auditors in small and medium sized audit firms around Klang Valley. A total of 100 questionnaires were distributed and the number of usable questionnaires was 81. Findings indicate that auditor's experience and auditor's accountability have a significant effect on audit quality. This research thus contributes to standard setters, regulators, policymakers and other audit firms by providing evidence with regard to the determinants of audit quality judgment in Malaysian small and medium audit firms.
\end{abstract}

Keywords: audit quality, small and medium audit firms, audit judgments, accountability, audit experience.

\section{ARTICLE INFO}

Article History:

Received: 24 May 2021

Accepted: 8 November 2021

Published: 1 December 2021

* Corresponding author: Aida Hazlin Ismail. Email: aidah348@uitm.edu.my 


\section{INTRODUCTION}

In Malaysia, small and medium-sized audit firms are often thought to be the majority of auditors used by small and medium-sized enterprises (SMEs). Evidence and theory of scope indicate that SME owners and managers employ external guidance sources and support services primarily owing to their internally based resource gaps. In the new era of technology and globalization, SMEs need to be able to survive, as the acquisition of resources is a dominant way to guide their own survival and development. As SMEs must deal with this resource gap and to change the environment; it has generated a position for small and medium-sized practices (SMPs) as vital company consultants. SMPs are the accounting practices whose clients are predominantly SMEs and which use external sources to supplement limited internal development resources and have a limited number of qualified staff. However, small and medium audit firms are commonly associated with lower audit quality. In addition, complying with International Standard of Quality Control 1 implementation is a major hurdle to small and medium audit practitioners (Normah \& Johari, 2007). Most audit quality research in the past typically supported that big audit businesses offer a high degree of audit quality. Hence, the firm size is often used as audit quality measurement (Baxter \& Cotter, 2009; Adeyemi \& Fagbemi, 2010). Dopuch and Simunic (1982) indicated that a higher quality of services are delivered by larger accounting firms, as they have a more significant reputation for protection. However, the crash of Arthur Andersen indicated that "big" may not always be better and could thus threaten the assertion that the high audit quality is linked to more significant auditors. Since Arthur Andersen's collapsed in 2002, small-medium audit firms are conducting audits for about $30 \%$ of publicly traded businesses and their market share has grown. There are also claims as to why the Big 4 and small-medium firms can serve a similar audit quality. Firstly, is because both the Big 4 auditors and SMPs conform to the same law and profession, and both types of audit firms must meet suitable standards of quality. Secondly, because the auditors in small-and medium-sized firms have a better knowledge of local and client market relations (Louis, 2005). Hence, these variables may allow them to detect irregularities better. The issue of audit quality occurs within SMEs when they lack powerful internal control systems, which is a prerequisite for an unqualified or clean audit opinion. Consequently, audit quality by auditors is a public issue. Research studies have indicated that auditors' accountability 
has an impact on audit quality (Yuliyanti \& Budiono (2006), Muliani Singgih (2010), Barzideh and Kheirol-lahi (2012), Bustami (2013), Saripudin et al. (2012) and Singgih and Bawono (2010). Hence, the essential objective of this research was thusly to differentiate the factors that could affect audit quality of SMPs in Malaysia, focusing on the top management support, experience and responsibility of the auditor.

\section{PROBLEM STATEMENT}

In the Enron scandal, Arthur Andersen, an auditor of Enron Corporation had abandoned its roles as an auditor by neglecting the improper accounting in the corporation's net income. This instance of a financial scandal shows that the review technique did not contemplate the potential areas of peril where misrepresentation could occur, where fraud could hamper audit quality. In Malaysia, the latest economic scandal relates to 1Malaysia Development Berhad (1MDB). IMDB is a financial scandal allegedly involving a large sum of cash and placing Malaysia under government scrutiny (Ali, 2016). Audit independence is clearly a problem when an audit is performed that may affect the quality of an audit. Hence, all these corporate scandals have affected the reputation of the audit profession, and audit quality is being questioned strongly. The credibility of auditors also has become more and more questionable as the auditors' function in identifying mistakes and fraud is debated by the public. Over the years, only the big four companies have been discussed and debated in relation to the audit quality problem worldwide. There is a lack of audit literature among small-medium audit firms that discuss audit quality problems. However in Malaysia, there are cases that involve Malaysia small-medium firms such as Aiwanna Manage Assets Sdn Bhd where the company's former director, Wahid Ali, was charged with three charges of omitting to state a material fact relating to the investment of Aiwanna's client, Eastern Pacific Industrial Corporation Bhd (EPIC). This shows that not only the big firms are involved in audit quality issues but also the small-medium firms. However, the Big audit firms do have internal checking and monitoring to control the audit quality of the firm but for small-medium firms there is no specific regulations or bodies that will track and monitor audit quality. The Malaysian Institute of Accountants (MIA) introduced the International Quality Control Standards 1 (ISQC 1) as part of Malaysia's approved audit standard in 2006. However, 
evidence has shown that ISQC 1 implementation in Malaysian small and medium-sized audit firms is somewhat limited (Omar \& Mohd Alwi, 2007). Small and medium-sized audit firms tend to function based on non-standard operating procedures, which are fundamentally inconsistent with the ISQC 1. Furthermore, compliance with the ISQC 1 implementation is a significant obstacle for small and medium audit practitioners (Omar \& Mohd Alwi, 2007). Research on the audit quality of small and medium audit practitioners is therefore essential in ensuring that all-important risks are examined and that public trust in the auditing profession is fixed. It also enables smallmedium audit firms to attain accountability and integrity, enhance activities, and instil confidence among people and stakeholders. Therefore, a research gap to be filled by this study is on variables that could have a substantial effect on the audit quality of Malaysia's small-medium practitioners. This research aimed to tackle the gap in the Malaysian context by defining the main characteristics that determine audit quality amongst small-medium audit firms in Malaysia. The research objectives were; 1) To investigate the relationship between top management support and audit quality in small and medium audit firm; 2) To examine the relationship between auditor's experience and audit quality of small and medium audit firms and; 3) To examine the relationship between auditor's accountability and audit quality of small and medium audit firms.

\section{LITERATURE REVIEW AND THEORETICAL UNDERPINNING}

The word 'audit quality' has different meanings around the world. However, there is no meaning in all of them, in achieving a globally recognized definition status. This is something that is complicated and therefore, it may be challenging to evaluate the quality of an audit. According to DeFond and Zhang (2014), audit quality can be defined as better assurance that the financial reports reflect the underlying economics faithfully and depends on their financial reporting and innate features. Crucean et al. (2019) said that one approach of defining the quality of an audit is the adequacy of the auditors' report. Did the auditor give a clean view when there was an error? Sailendra et al. (2019) defined audit quality as the probability of an auditors finding the customer's accounting system incompatible, when it is necessary to ensure professional and independent auditing commitment to users. 
According to the Financial Reporting Council (2006), audit quality is a complex concept, and there is no single agreed definition. Bedard, Johnstone, and Smith (2010) illustrated that "even seasoned professionals convening to discuss the notion of audit quality have difficulty agreeing on a common definition". As for Duff (2004), there is no proper definition of audit quality, although research on audit quality has been extensive. Quality audits involve auditors who apply a rigorous audit process and quality control procedures in accordance with applicable laws, regulations and standards. Auditors are responsible for conducting quality audits of financial statements. However, audit quality is best achieved in an environment where the supply chain of financial reporting provides support and appropriate interactions between participants. Each stakeholder plays an essential role in supporting highquality financial reporting and how they interact can affect the quality of an audit. The underpinning theory for this study is the Attribution Theory which is a social psychological theory that clarifies how individuals explain phenomena based on circumstances and logical results and how their motivation is influenced. This Theory refers to how someone explains the causes of the behavior of others or themselves which will be determined from whether it is internal such as nature, character, attitude, etc. or external such as the pressure of certain situations or circumstances that influence individual behavior (Heider, 1958). Therefore, the association of this theory with this study is that an auditor's behavior, which is the experience and accountability will best influence the level of the quality of the audit.

\section{HYPOTHESIS DEVELOPMENT}

\section{The Effect of Top Management Support on Audit Quality}

The top management prior studies is vague and is not consistent (Dong et al., 2009). Most argue that top management support is a set of important actions stemming from top management behaviours (Manfreda \& Stemberger, 2014). Other arguments for perceptions of management (Leonard-Barton \& Deschamps, 1988). Some even argue for both but have failed to draw many supporters (Basellier \& Pinsonneault, 1998). This decision makes the state of the definition unclear. It is, therefore, apparent that it is never adequately studied (Butler \& Fitzgerald, 1999). Literature indicates a high risk of improved performance at an organizational level 
when senior managers extend support (Williams \& Ramaprasad, 1996). The most logical reason for the most common behavioural top management support is that it is accessible through the management or by the company, which require supporting actions, to track and report on the actions. Recent literature shows management interaction influences the perceptions of employees regarding support, providing the employees with a sense of value and a contribution to the company that improves the quality of employees (Neves \& Eisenberger, 2012). Extensive research suggests that organizational interaction often relates to job efficiency. The perceptions of individuals of the strength of these factors relate adversely to conduct that reduces auditing quality and provides further potential auditing quality (Malone \& Roberts, 1996). Audit quality is positively impacted by open and direct interaction between top management and the auditor (Sarens \& De Beelde, 2006). The quality of an audit is significantly and positively affected by top management support, whilst budget availability, autonomy in audit technique, promotion and rewards, training and development have no effect on audit quality (Masood \& Afzal, 2016). Dawuda et al. (2017) revealed that management support services have shown a strong impact on the auditor's performance where the support will lead to risk prediction and serve management with approaches to avoid or mitigate the impacts of the risk. Organizational with strong loyalty and ethical culture support in attaining audit quality (Indrayati et al., 2021). According to Abate (2020), in her study on How Management Contributes to Audit Quality shows that the auditing process involves the management, the audit committee and the auditor. It is most effective, as in any relationship, if all partners are involved. A more streamlined, efficient and high-quality audit will come from planning, teamwork and open communication from all parties. Crucean et al. (2019), concluded that it must also be a constant worry for audit company managers who need to underline how significant their personnel training programmes are to improve the audit. It may be expected that an excellent training course will enable financial auditors to evaluate qualitatively all the phases of the audit procedure.

Additional factors such as incentives, motivation and good communication between the auditor and top management may also affect audit work (Masood \& Lodhi, 2015). Based on the literature review, the following hypothesis was proposed: 
$\mathbf{H}_{1}$ : Top Management Support positively influences audit quality in small and medium audit firms in Malaysia

\section{The Effect of an Auditor's Experience on Audit Quality}

The experience of an auditor effects audit quality and this may enhance the knowledge of the auditor to become more developed and the auditor always carries out audits according to the knowledge he/she auditor possesses. That qualifies the resulting audit report (Haeridistia \& Agustin, 2019). Study by Kuntari et al. (2017) and Jatiningsih and Purwaningtyas (2019) showed that an auditor's experience is one of the determinant factors that can affect audit quality where the experience is define based on the duration of work in auditing and the number of tasks of inspection performed. Prasanti et al. (2019) found that experienced auditors may easily detect any misstatements. The auditor will use all the expertise acquired to conduct the next work well so that the results of the audit will be better than before. Anggrainy et al. (2018) stated that an auditor's experience has a significant effect on audit quality. Crucean et al. (2019) deduce that the auditor's experience raises audit quality with the mandate of the auditor, while the auditor obtains a greater understanding of the system, the environment of the business, the client's industry and internal controls. While according to Mulyani (2020), an auditor's experience partially had a significant effect on audit quality. Kolodner's (1996) argued that experience is one of the significant variables to improve quality in carrying out a job. Experienced auditors can significantly influence producing better audits compared to inexperienced auditors, and it will shape an auditor's personality, which will make him/her wiser both in thinking and acting. This is in line with the findings of DeFond and Francis (2005), Smith (2009), Wang et al. (2012) and Kuntari et al. (2017). Zahmatkesha and Rezazadeh (2017) revealed that an auditor's experience positively affects audit quality. The study identified that a high audit quality was influenced by more experienced employee/staff. Bouhawia et al. (2015) supported the nation that an auditor's experience has a significant impact on the quality of audit results when it relates to the company's working environment. However, it contradicts with Kertarajasa et al. (2019) whereby experience did not have a significant effect on audit quality. Experience has no critical impact on the quality of the audit. Latercia et al. (2020) and Dewi et al. (2019), stated that experience does not significantly affect audit quality. This shows that the higher the experience 
of the auditor when auditing does not guarantee a higher quality audit, it can be caused by several things, such as task deadlines and the number of audit tasks being carried out. This outcome also supports the findings of Ashton (1990), Singgih and Bawano (2010), Suyono (2012), Samsi et al. (2013), and Furiady and Kurnia (2015) who showed that experience does not influence the quality of an audit but does not support the study results from Sukriah et al. (2009), Ramadhanis (2012), Saripudin et al. (2012), Parasayu and Rohman (2014), Cahan and Sun (2015), Pandoyo (2016), Wardayanti (2016), Dwitariani and Suputra (2016), Oktarini and Ramantha (2016), Rahayu and Suryono (2016), Ningrum and Budiartha (2017), showing that experience has a positive effect on audit quality. Based on the literature review, the following hypothesis was proposed:

$\mathbf{H}_{2}$ : Auditor's experience positively influences audit quality in small and medium audit firms in Malaysia

\section{Effect of Auditor's Accountability on Audit Quality}

Accountability from the auditor in completing the audit work likewise influences audit quality. Cloyd (1997) analysed the relationship between accountability and audit quality where accountability includes three measurements, which are motivation, dedication to the profession and social obligation, where these measurements positively effect audit quality in general. Ilmiyati and Suhardjo (2012) also revealed that accountability and competence of auditor's positively affect audit quality. Furiady and Kurnia (2015) supports the notion that competency, accountability and objectivity has a significant effect on audit quality. Accountability has a massive impact on audit quality where he demonstrates that when an auditor can finish the audit function admirably and on schedule, persuaded that his work is deliberately inspected and checked on by the supervisor, and being accountable to the business will increase the quality of an audit (Zahmatkesha \& Rezazadeh, 2017). According to Sangkala et al. (2018), the level of individual accountability in executing a job dictates how information is processed and the outcome will influence the response, decision or action to be done to influence the quality of the work of auditors. Hedar and Grahita (2018) have shown a considerable impact on audit quality where motivation reflects the auditor's commitment to deliver the audit results at phases. Putra et al. (2019) showed that the quality of the results of the audit is affected by 
accountability. The higher the accountability, the higher the quality of the audit results. Muslim and Hajering (2020) revealed that accountability has a positive and significant effect on audit quality in which the formulation of the accountability variable, motivation is the most dominating indicator and the social responsibility indicator offers the least percentage. Increasing auditor accountability to investors without financial accountability to managers boosts audit quality significantly and offers possible benefits in eliminating management control over the auditor selection process (Hurley et al., 2018). This is supported by previous research that accountability has a positive effect on audit quality. Yuliyanti and Budiono (2006), Muliani Singgih (2010), Barzideh and Kheirol-lahi (2012), Bustami (2013), Saripudin et al. (2012) and Singgih and Bawono (2010). Therefore, based on these arguments, the following hypothesis was proposed:

$\mathbf{H}_{3}$ : Auditor's Accountability positively influences audit quality in small and medium audit firms in Malaysia

\section{RESEARCH FRAMEWORK}

The discussed factors are illustrated in Figure 1.0.; specifically, top-level management support, auditor's experience and auditor's accountability (independent variable) that affect audit quality (dependent variable) of small and medium-sized auditors.

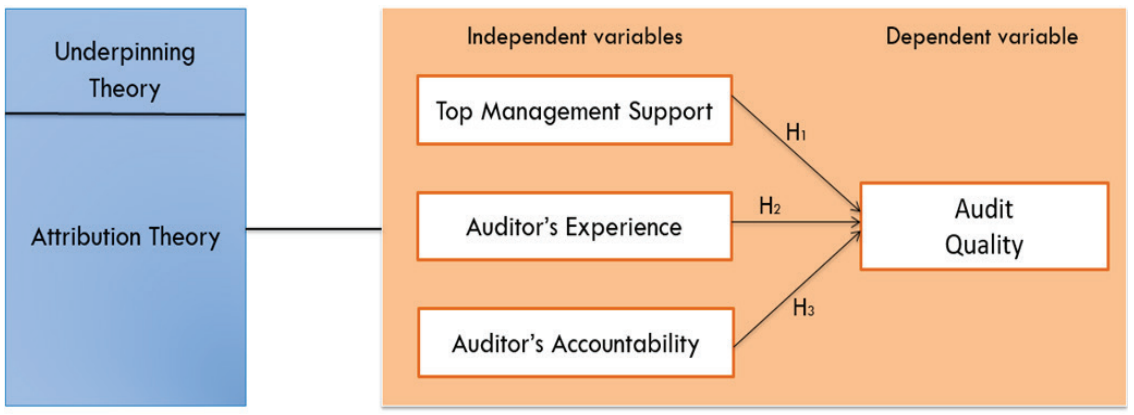

Figure 1.0: The Influence of Top Management Support,

Experience and Accountability on Audit Quality amongst Small-Medium Sized Audit Firms in Malaysia 
Figure 1.0 signifies the independent variables, which are top management support, auditor's experience and auditor's accountability, might influence the dependent variable, which is audit quality.

\section{RESEARCH METHODOLOGY}

\section{Population and Sample of the Study}

The population of this study was the auditors from small-medium sized audit firms registered as MIA members. As of 31 May 2019, there were 1482 registered member firms providing audit services. The sample respondents in this research were narrowed to auditors who worked in small-medium audit firm around the Klang Valley as it is the region with the highest number of small-medium audit firms in Malaysia with the total number of 505 audit firms. The Klang Valley comprises Federal Territory and Selangor. The sampling method of this research was purposive sampling in which the samples were chosen based on the aim of the study. This technique was appropriate for this research since the objective was to explore the connection between the quality of the audit and the top management support, the experience of the auditors as well as the accountability of the auditor among small-medium size audit firms. The auditors in the selected firms are, therefore, suitable respondents in this research to provide feedback on factors influencing audit quality of the SMPs. The level and position of auditors chosen to engage in this research were Partners, Managers, Assistant Managers, Senior Auditors and Staff Auditors from small and medium-sized audit firms who possessed specific expertise, professional skills, and vast experience in the audit process so that they will be able to provide accurate data required for this research. The sample size of the study was justified accordingly based on Bartlett, Kotrlik, and Higgins (2001), who indicated that for continuous data with a margin error of 0.03 and an alpha level of 0.05 as well as a population of 600 , the sample size should be approximately 100 respondents.

\section{Measurement of Variables and instrument for the study}

The instrument used to collect the data was the questionnaire survey method. The questionnaires were distributed to 100 auditors working in small and medium-sized audit firms in the Klang Valley. The survey 
contained five parts. Section A referred to demographic information; top management support measured was covered by Section B; the audit experience measurements were captured by Section C; the auditor's accountability measurement was covered in Section $\mathrm{D}$, and the last section was audit quality measurement. The measurement of variables was based on a 5-point Likert scale ranging from Strongly Disagree-1 to Strongly Agree-5. Five respondents ranging from Partners, Managers, Assistant Managers, Senior Auditors and Staff Auditors with expertise, skills and audit experience were invited to join the pilot test. This pilot test was aligned with Hasnah et al. (2016) who used five auditors from the MIA list for pre-testing the questionnaire. Feedback and comments identified from the questionnaires and other potential weaknesses, were recorded and improvements were made accordingly. Table 1.0 illustrates a review of the previous literature on the estimation of the variables in this analysis.

Table 1.0: Summary of the Development of the Research Instrument

\begin{tabular}{lll}
\hline & \multicolumn{1}{c}{ Variables of the Study } & \multicolumn{1}{c}{ Source of Reference } \\
\hline Dependent Variable: & Audit Quality & $\begin{array}{l}\text { Massod and Afzal (2016) } \\
\text { Fuad Elmahedi H.Bashir (2013) }\end{array}$ \\
Independent Variable: & Top Management Support & PCAOB's (2013) \\
& Auditor's Experienced & Kamuruchi (2016) \\
& Auditor's Accountability & Reni Febriyanti (2014) \\
\hline
\end{tabular}

\section{Data Collection and Analysis}

This research used primary data sources specifically self-administered electronic questionnaires distributed randomly through email to the selected participants. A cover letter was enclosed to every questionnaire to protect the respondent's identity and clarify the objectives of the survey. Data collection took place from early September 2019 to early October 2019. A total of 81 questionnaires from 100 questionnaires distributed were returned to the researcher with a response rate of $81 \%$. Data collected were coded and analyzed using Windows IBM SPSS version 22. 


\section{Data Analysis}

\section{Multiple Regression Analysis}

The aim of this study was to examine the effect of top management support, auditor's experience and auditor's accountability in audit quality in Malaysian small and medium audit firms. Hence, a regression analysis was used to analyse the data.

\begin{tabular}{|ll|}
\hline $\mathrm{AQ}=$ & $\alpha+\beta_{1} \mathrm{AI}+\beta_{2} \mathrm{AE}+\beta_{3} \mathrm{AA}+\varepsilon$ \\
Where: & \\
$\mathrm{AQ}$ & $:$ Audit Quality \\
$\mathrm{AI}$ & $:$ Auditor's Independence \\
$\mathrm{AC}$ & $:$ Auditor's Experience \\
$\mathrm{AA}$ & $:$ Auditor's Accountability \\
$\alpha$ & $:$ Constant or intercept \\
$\varepsilon$ & $:$ Error \\
\hline
\end{tabular}

\section{Reliability Test}

Based on Table 2.0 below, the dimensions for Top Management Support, Auditor's Experience and Auditor's Accountability were in the range of $.807, .888$ and .881 , respectively. The Cronbach's alpha for the dependable variable overall was in the range of .875 . Based on the Cronbach's alpha for both the independent and dependent variables above, the score was higher than .75. Therefore, the values of Cronbach's alpha for this study were considered reliable and valid. The items were further used for data analysis purpose.

Table 2.0: Cronbach's Alpha Score for the Independent and Dependent Variable Dimensions $(\mathrm{N}=\mathbf{8 1})$

\begin{tabular}{clcc} 
Section & \multicolumn{1}{c}{ Variables } & No. of Statement & Cronbach's alpha \\
\hline B & TopManagement Support & 10 & .807 \\
C & Auditor's Experience & 6 & .888 \\
D & Auditor's Accountability & 5 & .881 \\
E & Audit Quality & 8 & .875 \\
\hline
\end{tabular}




\section{Normality Test}

Results of the normality test showed that for all the variables, the Skewness and Kurtosis were between -1.145 and 2.879. Distribution of Skewness and Kurtosis between -2 and +2 (George \& Mallery, 2010) is considered as normal. It means that the average rating is normally distributed for Top Management Support, Auditor's Experience, Auditor's Accountability and Audit Quality.

\section{Correlation Analysis}

Based on the correlation analysis for all the variables as shown in Table 3.0, illustrate that all the three independent variables had a weak relationship and an insignificant correlation with audit quality.

Table 3.0: Correlation Analysis

\begin{tabular}{lcccc}
\hline \multicolumn{1}{c}{ Variables } & $\begin{array}{c}\text { Technology } \\
\text { Complexity }\end{array}$ & $\begin{array}{c}\text { Top } \\
\text { Management } \\
\text { Commitment }\end{array}$ & $\begin{array}{c}\text { Industry } \\
\text { Pressure }\end{array}$ & $\begin{array}{c}\text { Technology } \\
\text { Adoption }\end{array}$ \\
\hline $\begin{array}{l}\text { Technology Complexity } \\
\begin{array}{l}\text { Top Management } \\
\text { Commitment }\end{array}\end{array}$ & 1 & & & \\
Industry Pressure & $0.228^{*}$ & 1 & & \\
Technology Adoption & $0.331^{* *}$ & $0.429^{* *}$ & 1 & 1 \\
\hline${ }^{*}$ Correlation is significant at the 0.05 level (2-tailed). & -0.101 & $-0.226^{*}$ & $-0.306^{* *}$ & 1 \\
${ }^{* *}$. Correlation is significant at the 0.01 level (2-tailed). & & & \\
\end{tabular}

\section{Multiple Linear Regression}

Table 4.0: Coefficients

\begin{tabular}{lccc}
\hline \multicolumn{1}{c}{ Model } & \multicolumn{2}{c}{$\begin{array}{c}\text { Unstandardized } \\
\text { Coefficients } \\
\text { B }\end{array}$} & $\begin{array}{c}\text { Standardized Error } \\
\text { Coefficients } \\
\text { Beta }\end{array}$ \\
\hline (Constant) & 1.940 & .507 & .132 \\
Top Management Support & .127 & .106 & .118 \\
Auditor Experience & .102 & .109 & .345 \\
Auditor Accountability & .311 & .107 & \\
\hline
\end{tabular}




\section{Dependent Variable: Audit Quality}

The model showed a linear relationship between Top Management Support, Auditor's Experience and the Auditor's Accountability. This model was significant. A shown in Table 5.0 Top Management Support with a $\mathrm{p}$-value $=.232>.05$ and a significance level of $(\alpha=.05$. $)$ revealed that Top Management Support dids not have a significant impact on Audit Quality. Nonetheless, the p-value for Auditor's Experience $=.001<.05$, indicated that Audit Quality at the .05 significance level $(\alpha=.05)$ was influenced by the Auditor's Experience and Auditor's Accountability. The study found a relationship between the coefficient of Top Management Support (0.132), Auditor's Experience (0.118) and Auditor's Accountability (0.345), meaning that an increase in Top Management Support, Auditor's Experience and Auditor's Accountability increases Audit Quality.

Table 5.0: Estimated Regression Equation

\begin{tabular}{lccc} 
Variable & Coefficient & $\boldsymbol{t}$-value & $\boldsymbol{p}$-value \\
\hline Top Management Support & 0.132 & 1.205 & .232 \\
Auditor's Experience & 0.118 & 0.934 & $.001^{*}$ \\
Auditor's & 0.345 & 2.906 & $.005^{*}$ \\
Accountability & & & $0.000^{*}$ \\
\hline F & 7.534 & & \\
$\mathrm{R}^{2}$ & & .227 & \\
\hline
\end{tabular}

${ }^{*}$ significant at $5 \%$ level (2-tailed)

\section{DISCUSSION, LIMITATIONS AND FUTURE RESEARCH}

The study predicted that auditor's experience and auditor's accountability have a positive influence on audit quality. The Attribution Theory was employed to see the relationship between the three independent and dependent variables. The theory suggests that auditor's experience and accountability is important in determining audit quality. Therefore, the enhancement of audit quality is seen as the principal variable for the auditors in increasing public trust of their profession. Thus, maintaining accountability and experience are the cornerstone for auditors when providing reasonable assurance of audit quality. The first objective of this study was to examine the relationship between top management support 
and audit quality. The results revealed that there was an insignificant and positive relationship between top management support and audit quality, however the results are not in similar to previous studies conducted by Igbaria and Greenhaus (1992), Sarens and De Beelde (2006), Pathirage, Jayawardena, and Rajapaksha (2012), Ismail, Majid, Roosli, and Ab Samah (2014), and Masood and Lodhi (2015). The outcomes are controverting, where the top management does not influence audit quality. Different sized firms have a different level of resources. In small and medium audit firms, people at the top level are lesser compared to big firms. Auditors from small and medium size firms are used to such situations where they are still being independent and accountable in producing audit reports, even though they have minimal resources. Audit quality would endure its quality with or without the presence of top management support. This substantiates that an auditor is still able to present an accurate and fair audit report systematically. The second objective of the study was to see the relationship between auditor's experience and audit quality. In this study, the second hypothesis was also supported, which corresponded to previous literature by Rahayu and Suryono (2016), and Ningrum and Budiartha (2017). The auditor needs further education, training and experience in order to acquire professional skills, which the auditor reflects as a professional profession (Burns \& Haga, 1977). Problem solving knowledge is gained through specific and realistic experiences that goes to auditors who develop their knowledge and skills based on authentic experiences. The development of their knowledge will help them in auditing tasks and actual accounting. Therefore, in this study, the findings specified that the more experience the auditor, the better the audit quality. The argument that experienced auditors have positive effects on auditing quality was endorsed by Zahmatkesha and Rezazadeh (2017), who claimed that more exceptional audit quality was affected by experienced auditors. The findings also indicated that auditor's accountability seems to have a significant impact on audit quality. The last objective was to examine the relationship between auditor's accountability and audit quality. The findings were similar to Ilmiyati and Suhardjo (2012), where accountability and competency of auditors have positive effects on audit quality. Hence, the commitment and the implementation of social responsibility among the auditors would result in better quality audits provided by the auditors. If the auditor is accountable, work shall be completed with full effort in ensuring the auditors perform and complete the audit promptly, as stipulated by the audit standard. The auditor who is accountable will make the best effort in 
auditing and is not influenced by other parties. Therefore, the auditors will be able to act justly in making a reasonable judgement based on their rational reasons. When they are accountable, they can produce high audit quality reports. Accountable auditors will also be responsible for all their actions. The third hypothesis was supported as higher an auditor's accountability, the higher the quality of the audit. This is consistent with the result by Rusman et al. (2018) where an auditor's accountability is to deliver results according to the stage, and the auditor commits himself to complete the audit work in accordance with the contract of work.

The overall findings specified that auditor's experience and auditor's accountability met the expectations of the research objectives and hypotheses. The results provided vital evidence that auditor's experience and auditor's accountability had a significant influence on audit quality in small and medium-sized audit firms in Malaysia. This might have happened due to an auditor's accountability and responsibility in providing an accurate and fair view of the financial statements. Hence, auditors will perform and execute a better-quality audit. Besides, when the auditors have more experience, they will have more comprehensive knowledge and skills to perform more quality audits and at the same time provide substantiated opinions on financial statements professionally. Consequently, this confirms the underpinning 'Attribution Theory' in the audit quality literature, which indicates that the more experience and accountable the auditors, the better the quality of the audit. Hence, users will gain more confidence in the financial statement and audit reports.

\section{REFERENCES}

Abate, T. (2020, June 9). How management contributes to audit quality. IFAC. https://www.ifac.org/knowledge-gateway/supporting-internationalstandards/discussion/how-management-contributes-audit-quality.

Adeyemi, S. B., \& Fagbemi, T. O. (2010). Audit quality, corporate governance and firm characteristics in Nigeria. International Journal of Business and Management, 5(5), 169-179.

Ali, A. M. (2016). 1MDB: The Auditor General Office's Questions. Journal of Public Administration and Governance, 6(1), 50-72. 
Anggrainy, A. C., \& Andreas, \& Supriono (2018). The Effect of Competence, Independence and Work Experience on Audit Quality with Auditor Ethics as A Moderating Variable (Empirical Study at Public Accountant Office in South Jakarta Area). Jurnal Online Mahasiswa (JOM) Bidang Ilmu Ekonomi. 4(2), 4044-4058.

Ashton, R. H. (1990). Pressure and performance in accounting decision settings: Paradoxical effects of incentives, feedback, and justification. Journal of Accounting Research, 28, 148-180.

Bartlett, J. E., Kotrlik, J., \& Higgins, C. (2001). Organizational research: Determining appropriate sample size in survey research. Information Technology, Learning, and Performance Journal, 19(1), 43-50.

Barzideh, F., \& Kheirollahi, M. (2012). Accountability, Time Pressure, and Suppression of Audit Evidence. Journal of Audit Science, 11(45), 4-27.

Baxter, P., \& Cotter, J. (2009). Audit committees and earnings quality. Accounting \& Finance, 49(2), 267-290.

Bedard, J. C., Johnstone, K. M., \& Smith, E. F. (2010). Audit quality indicators: A status update on possible public disclosures and insights from audit practice. Current Issues in Auditing, 4(1), C12-C19.

Bouhawia, M. S., Irianto, G., \& Baridwan, Z. (2015). The effect of working experience, integrity, competence, and organizational commitment on audit quality (Survey state owned companies in Libya). IOSR Journal of Economics and Finance, 6(4), 60-67. doi:10.9790/5933-06426067

Burns, D. C., \& Haga, W. J. (1977). Much ado about professionalism: A second look at accounting. Accounting Review, 52(3), 705-715.

Bustami, A. (2013). (The influence of independence, accountability and auditor professionalism on quality audit) Pengaruh independensi, akuntabilitas dan profesionalisme auditor terhadap kualitas audit (Master's thesis). Jakarta, Indonesia: Universitas Islam Syarif Hidayatullah. 
Butler, T., \& Fitzgerald, B. (1999). Unpacking the Systems Development Process: An Empirical Application of the CSF Concept in a Research Context. The Journal of Strategic Information Systems, 8(4), 351-371.

Cahan, S. F., \& Sun, J. (2015). The effect of audit experience on audit fees and audit quality. Journal of Accounting, Auditing and Finance, 30(1), 78-100. https://doi.org/10.1177/0148558X14544503

Cloyd, C. B. (1997). Performance in tax research tasks: The joint effects of knowledge and accountability. Journal of Accounting Review, 72(1), 111-130.

Crucean, A. C., \& Hategan, C. D. (2019). The Determinants Factors on Audit Quality: A Theoretical Approach. Ovidius University Annals, Economic Sciences Series, 19(2), 702-710.

Dawuda, A., Ataribanam, S., \& Joseph, A. (2017). An exploratory study on management support services and its effects on the quality service delivery of internal auditors in the Northern Ghana. Internafional Journal of Accounfing Research, 5(2), 2-5.

DeFond, M. L., \& Francis, J. R. (2005). Audit research after Sarbanes Oxley. Auditing: A Journal of Practice \& Theory, 24(s-1), 5-30.

DeFond, M., \& Zhang, J. (2014). A review of archival auditing research. Journal of Accounting and Economics, 58(2-3), 275-326.

Dewi, R. N., Maulana, I., \& Muhadzib, M. (2019). The influence of auditor independence, work experience, work satisfaction, and auditor competency against audit quality. Indonesian Management and Accounting Research, 16(2), 46-65. 10.25105/imar.v16i2.4687.

Dong, L., Neufeld, D., \& Higgins, C. (2009). Top management support of enterprise systems implementations. Journal of Information Technology, 24(1), 55-80.

Dopuch, N., \& Simunic, D. (1982, June). Competition in auditing: An assessment. In Fourth Symposium on auditing research (Vol. 401, p. 405). Urbana, IL: University of Illinois. 
Duff, A. (2004). Auditqual: Dimensions of audit quality. Edinburgh: Institute of Chartered Accountants of Scotland.

Dunakhir, S. (2016). Factors Associated with Audit Quality: Evidence From an Emerging Market. Asia Pacific Journal of Advanced Business and Social Studies, 2(2).

Dwitariani, I. G. A., \& Suputra, I. D. G. D. (2016). Integritas Sebagai Pemoderasi Pengaruh Pengalaman Auditor Pada Kualitas Audit. E-Jurnal Akuntansi Unversitas Udayana, 16(3), 1744-1770. Retrieved from https://ojs.unud.ac.id/index.php/Akuntansi/issue/view/2122

Financial Reporting Council (2006), Promoting Audit Quality, Discussion Paper, Financial Reporting Council, available at: www.frc.org.uk/OurWork/Publications/FRC-Board/Discussion-Paper-Promoting-AuditQuality.pdf (accessed 21 July 2014).

Furiady, O., \& Kurnia, R. (2015). The Effect of Work Experiences, Competency, Motivation, Accountability and Objectivity towards Audit Quality. Procedia-Social and Behavioral Sciences, 211, 328-335. doi:10.1016/j.sbspro.2015.11.042

George, D., \& Mallery, P. (2010). SPSS for windows a step by step: A simple guide and reference. Boston, MA: Pearson Education, Inc.

Haeridistia, N., \& Agustin. (2019). The effect of independence, professional ethics \& auditor experience on audit quality. International Journal of Scientific and Technology Research, 8, 24-27.

Hajering, M. S. (2019). Moderating Ethics Auditors Influence of Competence, Accountability on Audit Quality. Jurnal Akuntansi, 23(3), 468-481. 10.24912/ja.v23i3.614.

Hasnah, H., Ishak, I., Yuvaraj, G., and Zulhawati, H. (2016). Audit exemption for small and medium enterprises: Perceptions of Malaysian auditors. Asian Academy of Management Journal, 21(2), 153-182. http://dx.doi. org/10.21315/aamj2016.21.2.7 
Hurley, P. J., Mayhew, B. W., \& Obermire, K. M. (2019). Realigning auditors' accountability: Experimental evidence. The Accounting Review, 94(3), 233-250. 10.2308/accr-52224.

Igbaria, M., \& Greenhaus, J. H. (1992). Determinants of MIS employees' turnover intentions: A structural equation model.Communications of the ACM, 35(2), 34-49.

Ilmiyati, F., \& Suhardjo, Y. (2012). Pengaruh akuntabilitas dan kompetensi auditor terhadap kualitas audit [The effect of accountability and auditor competence on audit quality]. Juraksi, 1(1), 43-56.

Indrayati, G. C., \& Supanto, F. (2021). The Influence of Audit Quality on Auditor Performance with Mediating Organizational Commitment and Organization Culture. Journal of Southwest Jiaotong University, 56(2), 350-364. 10.35741/issn.0258-2724.56.2.28.

Ismail, A. H., Mohd-Sanusi, Z., \& Isa, Y. (2008, Dec). Implementation of audit quality control system: Preliminary evidence from small and medium audit practices in Malaysia. Paper presented at the 9th Asian Academic Accounting Association Annual Conference, Dubai, United Arab Emirates.

Ismail, D., Majid, T. A., Roosli, R., \& Ab Samah, N. (2014). Project management success for post-disaster reconstruction projects: international NGOs perspectives. Procedia Economics and Finance, 18, 120-127. https://doi.org/10.1016/S2212-5671(14)00921-6.

Jatiningsih, D. E. S., \& Purwaningtyas, A. B. (2019, November). Audit Quality: Re-Testing Auditor's Competence, Professionalism and Working Experience at Public Accounting Firms in Yogyakarta. In 5th International Conference on Accounting and Finance (ICAF 2019) (pp. 27-32). Atlantis Press.

Karnawati, Y., Sururi Afif, A., Handayani, S., \&amp; Jusuf. (2018). Effect of Audit knowledge, work experience, and gender on Audit quality in Jakarta City. Proceedings of the 1st International Conference on Recent Innovations. https://doi.org/10.5220/0009951905190524 
Kertarajasa, A. Y., Marwa, T., \& Wahyudi, T. (2019). The effect of competence, experience, independence, due professional care, and auditor integrity on audit quality with auditor ethics as moderating variable. Journal of Accounting, Finance and Auditing Studies, 5(1), 80-99.

Kolodner, J. L. (1996). Reconstructive memory: A computer model. Cognitive Science, 7(4), 281-328.

Kuntari, Y., Chariri, A., \& Nurdhiana, N. (2017). The effect of auditor ethics, auditor experience, audit fees and auditor motivation on audit quality. Sriwijaya International Journal of Dynamic Economics and Business, 1(2), 203-218. 10.29259/sijdeb.v1i2.203-218.

Latercia, C. E., Purba, N. B., \& Hayati, K. (2020). The Effects of Ethics, Experience, And Motivation of Auditors On Audit Quality at BPKP North Sumatera. ACCRUALS (Accounting Research Journal of Sutaatmadja), 4(02), 149-162. 10.35310/accruals.v4i02.583.

Leonard-Barton, D., \& Deschamps, I. (1988). Managerial influence in the implementation of new technology. Management Science, 34(10), 1252-1265.

Louis, H. (2005). Acquirers' abnormal returns and the non-Big 4 auditor clientele effect. Journal of Accounting and Economics, 40(1-3), 75-99.

M. (Ed.). (2013, May 30). Regression Analysis: How Do I Interpret R-squared and Assess the Goodness-of-Fit? Retrieved from https://blog. minitab.com/en/adventures-in-statistics-2/regression-analysis-how-doi-interpret-r-squared-and-assess-the-goodness-of-fit

Malone, C. F., \& Roberts, R. W. (1996). Factors associated with the incidence of reduced audit quality behaviors. Auditing, 15(2), 49.

Manfreda, A., \& Štemberger, M. I. (2014). Factors causing the relationship gap between top management and IS personnel. Journal of Enterprise Information Management, 27(2), 107-121. 
Masood, A., \& Afzal, M. (2016). Determinants of audit quality in Pakistan. Journal of Quality and Technology Management, 13(II), 25-49.

Masood, A., \& Lodhi, R. N. (2015). Factors affecting the success of government audits: A case study of Pakistan. Universal Journal of Management, 3(2), 52-62.

Mulyani, I. (2020). The Effect of Auditor Ethics, Auditor Experience, Audit Fees, and Auditor's Motivation on Audit Quality (Case study of a Public Accounting Firm in Semarang). MALIA: Journal of Islamic Banking and Finance, 3(2), 139-146.10.21043/malia.v3i2.6879.

Neves, P., \& Eisenberger, R. (2012). Management communication and employee performance: The contribution of perceived organizational support. Human Performance, 25(5), 452-464.

Ningrum, M. K. K., \& Budiartha, K. (2017). Etika Auditor Memoderasi Pengaruh Pengalaman Auditor, Kompetensi Dan Due Professional Care Pada Kualitas Audit. E-Jurnal Akuntansi Unversitas Udayana, 20, 615-644. Retrieved from https://ojs.unud.ac.id/index.php/Akuntansi/ article/view/29404/19367

Oktarini, K., \& Ramantha, I. W. (2016). Pengaruh Pengalaman Kerja Dan Kepatuhan Terhadap Kode Etik Pada Kualitas Audit Melalui Skeptisisme Profesional Auditor. E Jurnal Akuntansi Unversitas Udayana, 15, 754-783.

Omar, N., \& Mohd Alwi, M. J. (2007). International standard on quality control (ISQC 1): A survey report for the Malaysian Institute of Accountants (MIA). Working paper, Universiti Teknologi MARA, Selangor.

Pandoyo. (2016). The Effect of Auditor Competence, Independence, Audit Experience, Organizational Culture and Leadership Against Auditor Professionalism and Its Implication On Audit Quality. International Journal of Advanced Research, 4(5), 1632-1646. https://doi. org/10.21474/IJAR01 
Parasayu, A., \& Rohman, A. (2014). Analisis Faktor - Faktor Yang Mempengaruhi Kualitas Hasil Audit Internal (Studi Persepsi Aparat Intern Pemerintah Kota Surakarta dan Kabupaten Boyolali). Diponegoro Journal of Accounting, 3(2), 165-174. Retrieved from http://ejournal-s1. undip.ac.id/index.php/accounting

Pathirage, Y. D., Jayawardena, L. N. A. C., \& Rajapaksha, T. N. (2012). Impact of management support for team performance: A Sri Lankan case study in apparel industry. Tropical Agricultural Research, 23(3), 228 - 236. 10.4038/tar.v23i3.4660.

Pham, Tuyen \& Pham, Cuong \& Pham, Long. (2016). Top Management Support, Organizational Learning, Innovative Behavior, Employee Commitment and Organizational Performance of Manufacturing Companies in Hai Phong. International Journal of Financial Research. 7. 10.5430/ijfr.v7n3p54.

Prasanti, D. H., Ramadhanti, W., \& Puspasari, N. (2019). Effect of Independence, Work Experience and Competence on Audit Quality with Profesional Ethics as Moderating Variable. Jurnal Akuntansi Aktual, 6(1), 223-233. 10.17977/um004v5i32019p223.

Putra, M. I. S., Fakhruddin, R., Fahmi, I., Ibrahim, R., \& Djalil, M. A. (2019). The Effect of Audit Accountability, Knowledge, And Motivation on Quality of the Auditor's Work at Aceh Besar's Inspectorate Office, Province of Aceh, Indonesia. East African Scholars Publisher, Kenya, 2(8), 299-303. https://doi.org/ 10.36349.EASMB/2019.v02i08.006

Rahayu, T., \& Suryono, B. (2016). Pengaruh Independensi Auditor, Etika Auditor, Dan Pengalaman Auditor Terhadap Kualitas Audit. Jurnal Ilmu Dan Riset Akuntasi, 5(April), 1-16. Retrieved from https://ejournal. stiesia.ac.id/jira/article/download/1688/1647

Ramadhanis, S. (2012). Pengaruh kompetensi, kemandiriandan motivasi terhadap kualitas audit di inspektorat [The influence of competence, independence 76 and motivation to audit quality at inspectorate]. E-jurnal Binar Akuntansi, 2(1), 76-83. Retrieved from https://onlinejournal.unja.ac.id/index.php/JBA/article/view/1311 
Rusman, H., Chandrarin, G., \& Assih, P. (2018). The Effect of Audit Accountability and Audit Quality on Audit Opinion. European Journal of Economics, Finance and Administrative Sciences, (97), 134-139.

Sailendra, S., Murwaningsari, E., Mayangsari, S., (2019). The Influence of Free Float Shares and Audit Quality on Company Performance: Evidence from Indonesia. Audit Financiar, vol. XVII, no. 2(154), 274-282.

Samsi, N., Riduwan, A., \& Suryono, B. (2013). Pengaruh pengalaman kerja, independensi, dan kompetensi terhadap kualitas audit: Etika auditor sebagai variabel pemoderasi. Jurnal Ilmu dan Riset Akuntansi, 1(2), 207-226.

Sangkala, M., Muhammad Salameh, A. A., Mohmoud Jarrar, M. K., \& Sari Dewi, A. R. (2018). Effect of Accountability and Audit Knowledge On the Auditor Work Quality in Accounting Public Office Makassar. International Journal of Management and Applied Science, 4(6), 63-67.

Sarens, G., \& De Beelde, I. (2006). The relationship between internal audit and senior management: A qualitative analysis of expectations and perceptions. International Journal of Auditing, 10(3), 219-241.

Saripudin, Herawaty, N., \& Rahayu. (2012). Pengaruh Independensi, Pengalaman, Due Professional Care dan Akuntanbilitas Terhadap Kualitas Audit (Survei terhadap Auditor KAP di Jambi dan Palembang). E-Jurnal Binar Akuntansi, 1(1). Retrieved from https://online-journal. unja.ac.id/index.php/JBA/article/view/725

Singgih, E. M., \& Bawono, I. R. (2010). Pengaruh Independensi, Pengalaman, Due Professional Care dan Akauntabilitas Terhadap Kualitas Audit. Jurnal. SNA 13. Purwokerto.

Smith, E., Bedard, J. C., \& Johnstone, K. M. (2009). How good is your audit firm'. Bloomberg Business Week, June. Viewed 11 January $2012<$ http://www.businessweek.com/managing/content/jun2009/ ca20090626764988.htm> 
Sukriah, I., Akram, \& Inapty, B. A. (2009). Pengaruh pengalaman kerja, independensi, obyektifitas, integritas dan kompetensi terhadap kualitas hasil pemeriksaan. In Paper presented at the Simposium Nasional Akuntansi XII (SNA12), Universitas Sriwijaya.

Suyono, E. (2012). The effects of independence, experience, and accountability to the audit quality. Purwokerto, Indonesia: University of Jenderal Sudirman. Retrieved fromhttps://www.wbiconpro.com/110Eko.pdf

Wang, Y., Yu, L., Zhang, Z., \& Zao, Y. (2012). Engaging audit partner experience and audit quality. Working Paper at Xiamen University on January 2012, China.

Wardayati, S. M. (2016). The effects of accountability, objectivity, integrity, working experience, competence, independence and motivation of the examiner toward the quality of inspection results at the inspectorate of Lumajang regency. Pertanika, 24, 165-174.

Williams, J. J., \& Ramaprasad, A. (1996). A taxonomy of critical success factors. European Journal of Information Systems, 5(4), 250-260.

Yuliyanti S., \& Budiono, E. (2006). Effect of Independence, Experience, Due Professional Care, Dan Akuntabilitas on the Quality Audit, https: //repository.telkomuniversity.ac.id, date accessed 28/02/2016

Zahmatkesh, S., \& Rezazadeh, J. (2017). The effect of auditor features on audit quality. Tékhne, 15(2), 79-87. doi:10.1016/j.tekhne.2017.09.003 